\title{
KEPUASAN KERJA SEBAGAI VARIABEL MEDIATOR ANTARA GAYA KEPEMIMPINAN DAN TURNOVER INTENTION: STUDI KASUS PADA HOTEL DI BOGOR
}

\author{
EMPLOYEE SATISFACTION AS A MEDIATOR BETWEEN LEADERSHIP STYLE AND TURNOVER \\ INTENTION: CASE STUDY OF HOTEL IN BOGOR
}

\author{
Siti Komariah $^{*)}$, Anggraini Sukmawati**), dan Sadikin Kuswanto ${ }^{*}$ \\ *) Sekolah Bisnis, IPB University \\ Jl. Raya Pajajaran Bogor 16151 \\ ${ }^{* *}$ Departemen Manajemen, Fakultas Ekonomi dan Manajemen, IPB University \\ Jl. Agatis Kampus IPB Darmaga, Bogor 16680
}

\begin{abstract}
Employee turnover could be prevented by identifying the factors causing employee intention to leave the company. This study aimed to analyze the effect of leadership style on the turnover intention with job satisfaction as the mediator. Data were collected through questionnaires distributed to 130 employees in a three-star hotel in Bogor. The sampling method was a census. This study used the descriptive analysis method and Partial Least Square-Structural Equation Model (PLS-SEM) modeling to analyze the influence between variables. The results showed that authentic leadership style has a strong and significant influence on job satisfaction. It was reflected in the leaders who focus on goals, encourage open communication, and have the attitude to supervise and monitor irregularities and take corrective actions. Job satisfaction had a strong and significant influence on employee turnover intentions, reflected on supervision, working situation, recognition and appreciation, and promotion. Authentic leadership style had an insignificantly and weak influence on employee turnover intention. Authentic leadership style significantly influenced turnover intentions through job satisfaction.
\end{abstract}

Keywords: authentic leaderhip, communication, competency, partial least square (PLS-SEM), recognition and appreciation

\begin{abstract}
Abstrak: Turnover karyawan dapat dicegah dengan mengidentifikasi faktor - faktor yang menyebabkan keinginan karyawan untuk keluar dari perusahaan. Penelitian ini bertujuan menganalisis pengaruh gaya kepemimpinan terhadap turnover intention dengan kepuasan kerja sebagai variabel mediator. Data dikumpulkan dengan mendistribusikan kuesioner tertulis terhadap 130 orang karyawan yang bekerja di salah satu hotel bintang tiga di Kota Bogor. Pengambilan sampel dengan menggunakan teknik sensus. Penelitian ini menggunakan analisis deskriptif dan analisis permodelan Partial Least Square - Structural Equation Model (PLS-SEM) untuk menganalisis hubungan antar variabel. Hasil dari penelitian ini menunjukan bahwa gaya kepemimpinan otentik berpengaruh kuat dan signifikan terhadap kepuasan kerja karyawan. Gaya kepemimpinan otentik yang tercermin pada pemimpin yang fokus terhadap tujuan perusahaan, mendorong komunikasi terbuka dan pemimpin yang memiliki sikap mengawasi dan memantau penyimpangan dari aturan dan akan mengambil tindakan korektif atas penyimpangan tersebut. Kepuasan kerja memiliki pengaruh kuat dan signifikan terhadap turnover intentions karyawan, tercermin pada pengawasan, situasi pekerjaan, pengakuan dan penghargaan dan promosi. Gaya kepemimpinan otentik memiliki pengaruh tidak kuat dan tidak signifikan terhadap turnover intentions karyawan. Gaya kepemimpinan otentik akan memiliki pengaruh signifikan terhadap turnover intentions karyawan melalui kepuasan kerja.
\end{abstract}

Kata kunci: authentic leadership, kompetensi, komunikasi, partial least square (PLS-SEM), pengakuan dan penghargaan

\footnotetext{
${ }^{1}$ Corresponding author:

Email: sqkasim@gmail.com
} 


\section{PENDAHULUAN}

Hubungan kerja yang sehat antara manajemen dan bawahannya berkontribusi terhadap meningkatnya produktifitas dan kepuasan kerja bagi karyawan. Sehingga tujuan dari perusahaan dapat tercapai optimal (Long dan Perumal, 2014). Hubungan baik yang terjalin antara pimpinan dan bawahannya yang diterapkan dalam gaya kepemimpinan merupakan strategi penting dalam pengelolaan sumber daya manusia yang efektif dalam suatu perusahaan. Karyawan yang tidak sepakat dengan pimpinannya akan cenderung memilih keluar dari pekerjaannya. Hal ini disebabkan karena rendahnya dukungan sosial dari pimpinan terhadap karyawan tersebut (Zainuddin et al. 2015). Gaya kepemimpinan yang ditentukan oleh sikap transparansi, koordinasi, delegasi dan komunikasi berpengaruh nyata terhadap komitmen organisasi dan kinerja karyawan (Fabio et al. 2016).

Authentic leadership memiliki pengaruh terhadap employee engagement (Khan et al. 2017), work engagement dan work group identification (Azanza et al. 2015), psychological capital karyawan (Amunkette dan Rothmann, 2015), organizational commitment (Gatling et al. 2016), affective commitment (Oh dan Oh, 2017). Menurut Amunkette dan Rothmann (2015); Khan et al. (2017); Ayça, (2019) authentic leadership memengaruhi kepuasan kerja dan authentic leadership memiliki pengaruh tidak langsung terhadap turnover intentions (Gatling et al. 2016; Oh dan Oh, 2017; Amunkette dan Rothmann, 2015).

Gaya kepemimpinan yang melayani secara parsial berpengaruh positif dan signifikan terhadap kepuasan kerja (Novanda et al. 2018). Kashyap dan Rangnekar (2016) menyatakan bahwa pengaruh langsung kepemimpinan yang melayani terhadap turnover intentions karyawan adalah signifikan. Hal ini dapat diartikan bahwa kepemimpinan yang melayani dapat membantu memengaruhi keputusan karyawan untuk tetap bekerja atau keluar dari perusahaan. Menurut Wells dan Peachey (2011) Zainuddin et al. (2015) Gaya kepemimpinan transaksional memiliki pengaruh negatif dan signifikan terhadap turnover intentions. Menurut Wijaya dan Putra (2014) gaya kepemimpinan transaksional berpengaruh positif terhadap kepuasan kerja karyawan.
Kepuasan kerja karyawan adalah perasaan positif seseorang tentang pekerjaannya yang dihasilkan dari evaluasi karakteristiknya (Robbins dan Judge, 2017) Kepuasan kerja menjadi perhatian setiap perusahaan diberbagai industri untuk memenuhinya. Hal ini dikarenakan kepuasan keja dapat memengaruhi job performance (Kim dan Kim, 2017) dan turnover intentions (Nazarudin et al, 2016) (Mardiana et al, 2014) (Dusek et al, 2014) (Syahronica et al, 2015).

Turnover intentions adalah niat untuk meninggalkan organisasi untuk mencari pekerjaan baru (Azeez et al, 2016) turnover intentions diartikan sebagai keinginan untuk meninggalkan industri hospitality (Brown, 2011). Turnover intentions menjadi agenda penting para pemimpin dalam suatu perusahaan. Hal ini dikarenakan pemimpin harus menganalisa faktor yang menyebabkan turnover dan merekomendasikan pendekatan terbaik untuk mengatasi masalah tersebut. Sehingga dapat mempertahankan karyawan dalam perusahaannya untuk meningkatkan daya saing perusahaan di era globalisasi (Ongori, 2007). Menurut Ali dan Mohammad (2018) turnover intentions dianggap sebagai anteseden utama dari aktual turnover. Untuk itu mengurangi tingkat turnover dalam suatu bisnis yang baru dimulai akan berpengaruh terhadap produktifitas dan diperlukan pemulihan reputasi dan citra perusahaan.

Perkembangan industri perhotelan khususnya Kota Bogor beberapa tahun terakhir begitu pesat. Hal ini memengaruhi pertumbuhan investasi di Kota Bogor. Gunawan (2018) Kepala Dinas Penanaman Modal dan Pelayanan Terpadu Satu Pintu (DPMPTSP) Kota Bogor menyampaikan bahwa laju pertumbuhan investasi di Kota Bogor mengalami peningkatan di tahun 2018 masih didominasi bidang perdagangan dan jasa, seperti hotel, restaurant dan lain sebagainya.

Permasalahan yang ada pada salah satu hotel bintang tiga di Kota Bogor ini adalah tingginya tingkat turnover karyawan, rata - rata tingkat turnover pada tahun 2013 - 2017 sebesar 24,80\% melebihi rata - rata tingkat turnover karyawan dari lima hotel di Kota Bogor tahun 2017, yakni sebesar 9,6\% (data dihimpun dari beberapa hotel bintang tiga dan empat di Kota Bogor). Hal ini mengindikasikan tingginya niat atau keinginan karyawan untuk mengundurkan diri, secara umum permasalahan dari tingginya tingkat turnover tersebut adalah menurunnya produktifitas. Tingkat turnover tertera pada Gambar 1 


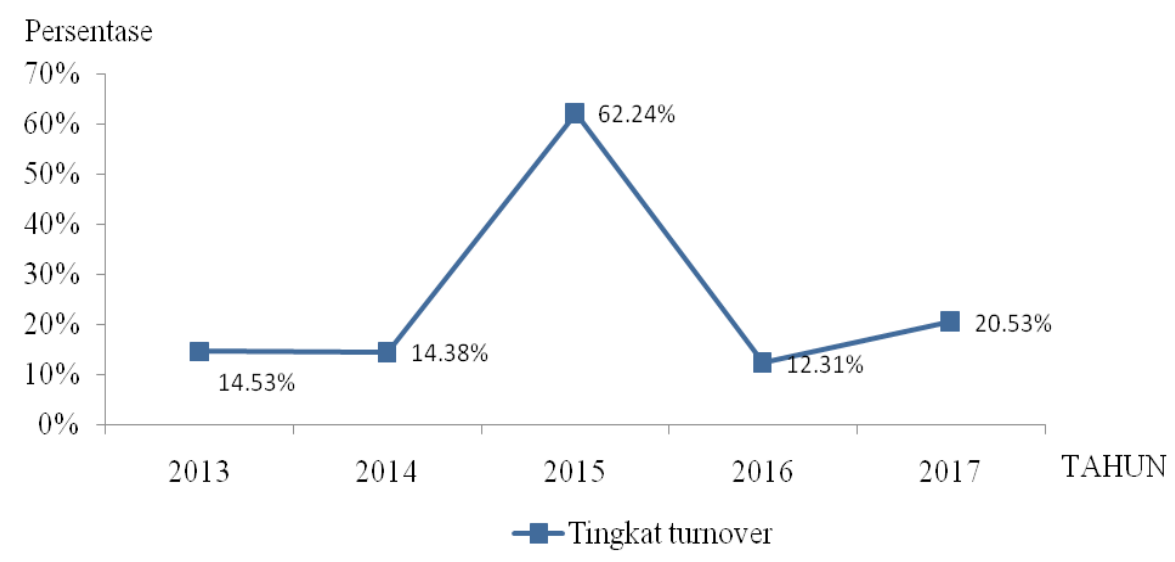

Gambar 1. Tingkat turnover karyawan

Chen et al. (2010) menyatakan bahwa tingkat turnover karyawan yang tinggi pada industri hospitality berpengaruh terhadap stabilitas operasional hotel. Hal ini disebabkan meningkatnya biaya yang berhubungan dengan rekrutmen karyawan dan kualitas pekerjaan yang menurun. Kualitas pekerjaan yang menurun berdampak terhadap kualitas pelayanan terhadap customer. Karyawan hotel akan keluar dari perusahaan karena gaji dan tunjangan yang rendah, lingkungan kerja yang tidak ramah dan kesempatan mengembangkan karir yang terbatas.

Gatling et al. (2016) menyimpulkan bahwa pengaruh authentic leadership terhadap turnover intentions dimediasi oleh organizational commitment, sifat positif authentic leadership sejalan dengan karakter positif dari pemimpin dan organisasi dalam menciptakan hubungan baik dengan customer, authentic leadership tepat untuk industri hospitality.

Amunkette dan Rothmann (2015) dalam penelitiannya mengemukakan bahwa authentic leadership secara tidak langsung memengaruhi intentions to leave melalui kepuasan kerja. Authentic leadership berhubungan positif dengan kepuasan kerja melalui psychological capital, kepuasan kerja berhubungan negatif dengan intention to leave karyawan.

Dalam penelitian Onyebu dan Omotayo (2017) terhadap karyawan yang bekerja di industri perhotelan menunjukan bahwa kepuasan kerja memengaruhi turnover intention. Faktor kepuasan kerja tersebut adalah gaji, promosi, kenyamanan kerja, dukungan rekan kerja, pengakuan dan penghargaan.
Syahronica et al. (2015) dalam penelitiannya menyimpulkan bahwa kepuasan kerja berpengaruh terhadap turnover intentions. artinya semakin tinggi tingkat kepuasan kerja akan menurunkan tingkat turnover intention karyawan. Zopiatis et al. (2014) dalam penelitiannya menyimpulkan bahwa ekstrinsik kepuasan kerja berpengaruh negatif dan siginifikan terhadap turnover intentions karyawan, sementara intrinsik kepuasan kerja tidak memiliki hubungan positif maupun negatif terhadap turnover intentions, namun dengan tidak adanya ekstrinsik kepuasan kerja dapat meningkatkan turnover intentions karyawan hotel.

Berdasarkan penelitian - penelitian yang telah dilakukan dapat disimpulkan bahwa apabila kepuasan kerja meningkat maka tingkat turnover intentions akan berkurang. Gaya kepemimpinan memengaruhi kepuasan kerja dan turnover intentions karyawan. Dalam penelitian ini memiliki kesamaan variabel yang diteliti sehingga hasil penelitian ini dapat mendukung temuan yang sudah ada sebelumnya. Penelitian ini memiliki perbedaan dari segi objek penelitian, alat analisis dan indikator - indikator yang digunakan untuk mengukur setiap variabel. Penelitian ini bertujuan untuk menganalisis pengaruh gaya kepemimpinan terhadap turnover intention dengan kepuasan kerja sebagai variabel mediator pada salah satu hotel bintang tiga di Kota Bogor. Untuk mengukur variabel bebas dalam penelitian ini gaya kepemimpinan memiliki tiga dimensi yakni gaya kepemimpinan otentik, gaya kepemimpinan yang melayani dan gaya kepemimpinan transaksional diukur dengan menggunakan kuesioner sebanyak 25 item pernyataan. Variabel kepuasan kerja memiliki dua dimensi yaitu dimensi intrinsik kepuasan 
kerja dan ekstrinsik kepuasan kerja, untuk mengukurnya menggunakan kuesioner yang diadaptasi dari Weiss et al.(1967) dengan menggunakan kuesioner sebanyak 31 item pernyataan. Weiss et al. (1967) mengembangkan Minnesota satisfaction questionnaire (MSQ) untuk mengukur teori pencocokan kerja dan kepuasan kerja karyawan dalam lingkungan pekerjaan.

Variabel turnover intentions memiliki tiga dimensi, yakni niat meninggalkan industri hospitality, niat meninggalkan industri hospitality dengan karir faktor dan niat untuk meninggalkan organisasi untuk mencari pekerjaan yang baru. Variabel tersebut diukur dengan menggunakan kuesioner sebanyak 14 item pernyataan.

\section{METODE PENELITIAN}

Data primer didapatkan dengan mendistribusikan kuesioner tertulis terhadap 130 orang karyawan yang bekerja di salah satu hotel bintang tiga yang berlokasi di Kota Bogor. Populasi dalam penelitian ini sebanyak 130 responden yang merupakan karyawan hotel tersebut. Pengambilan data sekunder dilakukan pada sejak Januari 2018, sedangkan pengambilan data primer pada Januari 2020. Pengambilan sampel dilakukan dengan menggunakan metode sensus. Data sekunder diperoleh dari data kepegawaian pada divisi kepegawaian, market share analysis, profit and loss report pada divisi sales dan marketing hotel. Untuk menganalisis hubungan antar variabel digunakan analisis data dengan menggunakan permodelan PLSSEM. Berdasarkan teori dan paparan tersebut dibuatlah kerangka penelitian tertera pada Gambar 2.

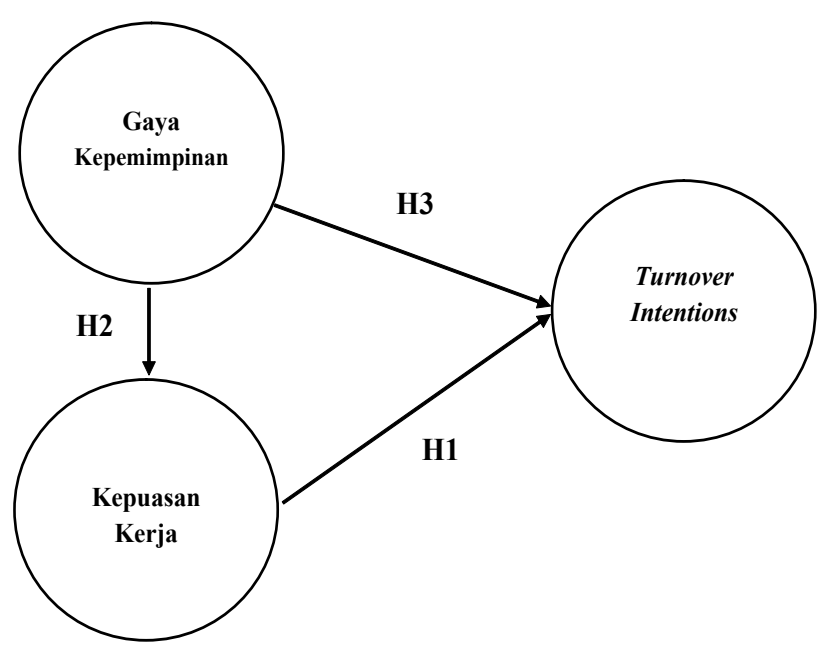

Gambar 2. Kerangka pemikiran
Hasil yang diharapkan dari penelitian ini adalah adanya pengaruh gaya kepemimpinan terhadap turnover intentions yang dimediasi oleh kepuasan kerja. Berdasarkan teori, paparan dan kerangka penelitian tersebut maka disusunlah hipotesis penelitian sebagai berikut:

H1: Kepuasan kerja memengaruhi turnover intentions

$\mathrm{H} 2$ : Gaya kepemimpinan memengaruhi kepuasan kerja

H3: Gaya kepemimpinan memengaruhi turnover intentions

\section{HASIL}

\section{Karakteristik responden}

Karakteristik responden berjenis kelamin laki - laki $81,54 \%$ responden berjenis kelamin perempuan $18,46 \%$. Status pernikahan responden diketahui telah menikah $66,15 \%$ responden yang belum atau tidak menikah $33,85 \%$. Usia responden relatif muda, usia $(36-45)$ tahun $28,46 \%,(25-35)$ tahun $26,92 \%$, usia $(18-24)$ tahun $24,62 \%$, sedangkan usia (46 - 56) tahun $20,00 \%$. Masa kerja responden, $(3-6)$ tahun $33,08 \%,(1-3)$ tahun $29,23 \%,>6$ tahun $22,31 \%,<1$ tahun $15,38 \%$. Latar belakang pendidikan SMA Sederajat $72,31 \%$, Diploma 11,54\% , Sarjana 9,23\%, lainnya 6,92\%. Posisi pekerjaan dari responden dalam penelitian ini posisi staff $72,31 \%$, supervisor $16,92 \%$, Asst Manager 3,85\%, Manager 6,92\%. Status kepegawaian responden karyawan kontrak $62,31 \%$, pegawai tetap $23,08 \%$, pegawai harian lepas sebanyak $14,62 \%$. Divisi pekerjaan responden Housekeeping 25,38\%, FB Product dan Pastry 17,69\%, FB Service, Lounge, dan Banquet 17,69\%, HRD dan Security 11,54\%, Front office 8,46\%, Engineering 7,69\%, Accounting 6,15\%, Sales \& Marketing 5,38\%

\section{Pengujian Outer model}

Pengujian validitas pada indikator peubah laten yakni indikator peubah gaya kepemimpinan, kepuasan kerja, dan turnover intentions dengan bantuan skala pengukuran loading 0,50 sehingga validitas konvergen dari model pengukuran akan terpenuhi jika nilai loading factor $>0,50$ (Ghozali, 2011). Pada Gambar 3 nilai loading factor pada masing - masing variabel dalam penelitian memiliki tingkat validitas yang tinggi sehingga validitas konvergen sudah terpenuhi. Pengujian reliabilitas dari konstruk dengan melihat 
hasil output dari composite reliability dengan bantuan skala pengukuran 0,70 konstruk dinyatakan reliable jika nilai composite reliability $>0,70$. Hasil uji reliabilitas penelitian ini tertera pada Tabel 1 .

Tabel 1. Nilai Composite reliability

\begin{tabular}{lcc}
\hline Konstruk & $\begin{array}{c}\text { Composite } \\
\text { Reliability }\end{array}$ & Keterangan \\
\hline Gaya Kepemimpinan & 0,942 & Reliable \\
Kepuasan Kerja & 0,939 & Reliable \\
Turnover Intentions & 0,927 & Reliable \\
\hline
\end{tabular}

Pada Tabel 1 dapat diketahui bahwa nilai hasil pengukuran composite reliability semua konstruk > 0,70 dengan demikian konstruk dalam penelitian ini dinyatakan sangat reliabel artinya indikator - indikator yang digunakan dalam penelitian ini mempunyai reliabilitas yang cukup baik atau mampu untuk mengukur konstruknya.

\section{Pengujian inner model}

Pada tahap inner model dilakukan evaluasi terhadap prosentasivarianceyang dijelaskan dalamnilai $R$-square $\left(\mathrm{R}^{2}\right)$. Nilai $\mathrm{R}^{2}$ digunakan untuk menggambarkan sejauh mana model dapat digambarkan melalui tiap variabel yang digunakan atau sumbangan pengaruh yang diberikan variabel bebas terhadap variabel terikat. Nilai $\mathrm{R}^{2}$ dalam penelitian ini tertera pada Tabel 2.

Tabel 2. Nilai R-square

\begin{tabular}{lcc}
\hline Variabel & R-Square & Keterangan \\
\hline Gaya kepemimpinan & & \\
Kepuasan Kerja & 0,585 & Moderate \\
Turnover intentions & 0,246 & Lemah \\
\hline
\end{tabular}

Berdasarkan Tabel 2 dapat diketahui bahwa gaya kepemimpinan menyumbang $58,5 \%$ terhadap variabel kepuasan kerja dimana sisanya $41,5 \%$ dapat digambarkan oleh faktor lain diluar model yang diteliti, pengaruh gaya kepemimpinan menyumbang 24,6\% terhadap variabel turnover intentions dimana sisanya $75,4 \%$ dijelaskan oleh faktor lain diluar model yang diteliti.

Nilai $\mathrm{R}^{2}$ sebagai pendekatan dalam menggambarkan model, dalam penelitian ini dapat digambarkan bahwa gaya kepemimpinan memiliki pengaruh besar terhadap variabel kepuasan kerja. Dalam upaya untuk meningkatkan kepuasan kerja hanya dengan meningkatkan gaya kepemimpinan. sehingga dapat disimpulkan berapa besar kepuasan kerja yang tergambarkan oleh gaya kepemimpinan. Kepuasan kerja memiliki pengaruh terhadap turnover intentions dimana faktor yang meningkatkan kepuasan kerja adalah gaya kepemimpinan sehingga secara tidak langsung gaya kepemimpinan memiliki pengaruh terhadap turnover intentions.

Pada Gambar 3 diketahui bahwa variabel gaya kepemimpinan (KP) memiliki tiga komponen yaitu gaya kepemimpinan yang melayani (KPM), gaya kepemimpinan transaksional (KPT), gaya kepemimpinan otentik (KPO). Gaya kepemimpinan otentik memiliki tiga indikator manifest yakni (KPO1) memberikan informasi, (KPO2) mendorong komunikasi terbuka, (KPO3) fokus kepada tujuan. Nilai koefisien jalur terbesar pada KPO sebesar 0,69 dan indikator manifest KPO3 dan KPO2 sebesar 0,72 dan 0,71 artinya gaya kepemimpinan otentik adalah gaya kepemimpinan yang memberi pengaruh besar terhadap gaya kepemimpinan di hotel tersebut. Hal ini tercermin pada pemimpin yang fokus terhadap tujuandan mendorong komunikasi terbuka.

Pada komponen KPM terdapat tiga indikator manifest diantaranya (KPM1) memberikan akses untuk berinteraksi, (KPM2) berkomunikasi dengan bawahannya dan (KPM3) memberikan dukungan terhadap bawahannya. Nilai koefisien jalur terbesar pada KPM2 sebesar 0,71 artinya atasan yang mengkomunikasikan dan menjelaskan tentang rencana dan pencapaian perusahaan memberikan pengaruh terbesar terhadap gaya kepemimpinan yang melayani. Pada komponen KPT terdapat dua indikator manifest (KPT1) menjanjikan imbalan untuk kinerja yang baik dan (KPT2) mengawasi dan memantau penyimpangan dari aturan standar yang ditetapkan dan mengambil tindakan korektif. Nilai koefisien terbesar pada KPT2 sebesar 0.62 artinya keterlibatan atasan dalam menerapkan standar operasional prosedur (SOP) pada setiap bidang pekerjaan yang dilakukan memberikan pengaruh besar terhadap gaya kepemimpinan transaksional.

Dari pembahasan dapat disimpulkan bahwa gaya kepemimpinan yang dapat diterapkan adalah gaya kepemimpinan otentik yang tercermin pada pimpinan yang fokus kepada tujuan perusahaan, mendorong komunikasi terbuka dan memantau penyimpangan dari aturan standar yang ditetapkan dan mengambil tindakan korektif. 


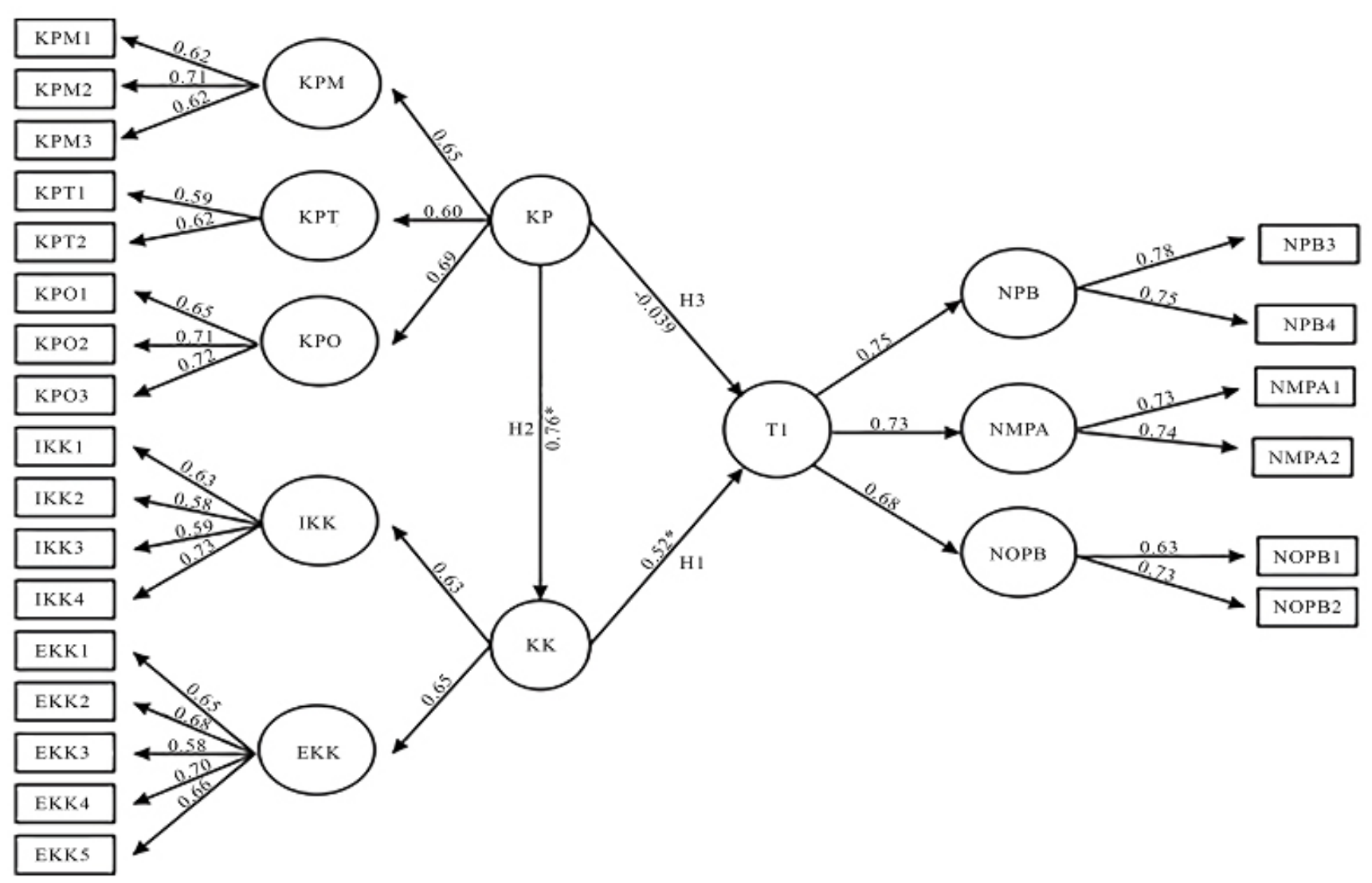

Gambar 3. Model akhir penelitian variabel, dimensi dan indikator penelitian

Variabel kepuasan kerja (KK) terbentuk atas dua komponen(EKK) ekstrinsik kepuasan kerja dengan nilai sebesar 0,65 dan (IKK) instrinsik kepuasan kerja sebesar 0,63. Pada komponen EKK terdapat lima indikator manifest yakni kenyamanan kerja (EKK1), pengawasan (EKK2), gaji dan tunjangan (EKK3), situasi pekerjaan (EKK4) dan isentif (EKK5). Nilai koefisien terbesar terdapat pada EKK4 dan EKK2 sebesar 0,70 dan 0,68 artinya pengawasan dan situasi pekerjaan memberikan pengaruh besar terhadap ekstrinsik kepuasan kerja. Komponen IKK terdiri dari empat indikator manifest yakni pengakuan dan penghargaan (IKK1), tanggung jawab (IKK2), pekerjaan (IKK3) dan promosi (IKK4). Nilai terbesar ada pada IKK4 dan IKK1 yakni 0,73 dan 0,63 . Artinya pengawasan dan promosi memberikan pengaruh besar terhadap intrinsik kepuasan kerja.

Dari paparan diatas dapat disimpulkan bahwa intrinsik dan ekstrinsik kepuasan kerja karyawan dipengaruhi oleh kompetensi dasar yang dimiliki oleh karyawan tersebut dan merujuk kepada kompetensi yang ditentukan oleh perusahaan. Kompetensi berpengaruh terhadap ektrinsik kepuasan kerja situasi pekerjaan dan semangat rekan kerja. Hal ini dapat diartikan bahwa semua karyawan dianggap cakap dan mampu bekerjasama dalam melakukan pekerjaannya, sehingga menciptakan semangat bekerja dan situasi lingkungan pekerjaan yang kondusif. Pengaruh kompetensi terhadap intrinsik kepuasan kerja pengakuan dan penghargaan dan promosi adalah karyawan dengan kompetensi tertentu membutuhkan pengakuan dan penghargaan dari perusahaan dan memiliki kesempatan lebih besar dalam program promosi.

Variabel turnover intentions (TI) terbentuk atas tiga komponen yakni niat meninggalkan industri hospitality (NPB) dengan nilai sebesar 0,75 niat untuk meninggalkan industri hospitality dengan karir faktor (NMPA) sebesar 0,73 niat untuk meninggalkan organisasi untuk mencari pekerjaan baru (NOPB) sebesar 0,68. Komponen NPB terdiri dari dua indikator manifest masa kerja pada posisi saat ini (NPB3) dan masa kerja di hospitality industri (NPB4) dengan nilai sebesar 0,78 dan 0,75 dapat diartikan bahwa karyawan dengan masa kerja tertentu dan pada divisi tertentu mengalami kejenuhan dalam bekerja memengaruhi niat untuk meninggalkan industri hospitality. Komponen NMPA memiliki dua indikator manifest yaitu bekerja di bidang hospitality (NMPA1) dan bekerja di luar bidang hospitality (NMPA2) dengan nilai sebesar 0,74 
dan 0,73 dapat diartikan bahwa bekerja di industri hospitality dengan jadwal kerja yang tidak teratur, kurangnya waktu untuk keluarga dan keinginan untuk mencari tantangan dan pengalaman baru untuk bekerja di luar bidang hospitality memengaruhi karyawan untuk meninggalkan industri hospitality dengan karir faktor.

Pada komponen NOPB terdiri dari dua indikator manifest yaitu social behavior (NOPB1) dan emosi (NOPB2) karyawan berniat meninggalkan organisasi untuk mencari pekerjaan baru karena ketidakcocokan dengan manajemen yang berjalan dan mencari lowongan kerja melalui internet.

Dari kajian di atas dapat disimpulkan bahwa turnover intentions karyawan dipengaruhi oleh masa kerja karyawan pada posisi saat ini. Sehingga menimbulkan kejenuhan dan berusaha mencari pekerjaan lain baik itu di bidang industri hospitality maupun di luar bidang industri hospitality. Mereka berharap mendapatkan pengalaman baru dan memiliki banyak waktu untuk keluarga. Turnover intentions juga dipengaruhi oleh ketidak cocokan karyawan dengan kebijakan manajemen yang berjalan pada saat ini. Mereka mencari lowongan pekerjaan tersebut melaluiinternet.

\section{Pengujian Hipotesis}

Uji hipotesis dalam penelitian ini dihitung berdasarkan nilai original sample, t-hitung dan nilai $\mathrm{p}$-value, hipotesis dapat diterima apabila t-hitung lebih besar dari nilai t-tabel $=1,96$ dengan taraf signifikansi 5\% tertera pada Tabel 3. Pada Tabel 3 dapat diketahui bahwa H1 hubungan kepuasan kerja terhadap turnover intentions mempunyai nilai t-statistik sebesar 4,38 $>1,96$ dapat diartikan terdapat pengaruh yang signifikan, maka H1 dapat diterima. Nilai original sample 0,525 menunjukan arah hubungan positif. Nilai p-value sebesar $0<5 \%$ menunjukan pengaruh kuat. Dapat disimpulkan bahwa kepuasan kerja berpengaruh kuat dan signifikan terhadap turnover intentions artinya semakin tinggi tingkat kepuasan kerja karyawan yang dirasakan oleh karyawan akan menurunkan tingkat turnover intentions. Faktor kepuasan kerja tersebut dicerminkan oleh pengawasan, situasi pekerjaan, pengakuan dan penghargaan dan promosi. Nilai koefisien positif dapat diartikan bahwa semakin tinggi nilai kepuasan kerja yang dirasakan karyawan, maka akan membuat karyawan tersebut semakin tidak ingin meninggalkan pekerjaannya. Hasil penelitian ini memperkuat hasil penelitian Mardiana et al. (2014), Widyasari et al. (2017) yang menyatakan bahwa kepuasan kerja berpengaruh signifikan terhadap turnover intentions karyawan. Semakin besar kepuasan kerja karyawan dalam perusahaan akan menurunkan tingkat turnover intentions karyawan. Hal ini berbanding terbalik dengan penelitian Yuda dan Ardana (2017) yang menyimpulkan bahwa kepuasan kerja berpengaruh negatif tidak signifikan terhadap turnover intentions karyawan Hotel Holiday Inn Bali Raya Kuta. Kepuasan kerja yang tinggi tidak serta merta menyebabkan rendahnya turnover intentions, sebaliknya ketidakpuasan kerja yang rendah tidak serta merta menyebabkan tingginya turnover intentions.

H2 - Hubungan gaya kepemimpinan terhadap kepuasan kerja mempunyai nilai t-statistik sebesar 13,697 > 1,96 terdapat pengaruh yang signifikan, maka $\mathrm{H} 2$ dapat diterima. Nilai original sample 0,765 menunjukan arah hubungan positif. Nilai p-value sebesar $0<5 \%$ menunjukan pengaruh kuat. Dapat disimpulkan bahwa gaya kepemimpinan otentik memiliki pengaruh positif kuat dan signifikan terhadap kepuasan kerja karyawan, artinya semakin tinggi gaya kepemimpinan yang dirasakan oleh karyawan maka semakin tinggi tingkat kepuasan kerja karyawan. Gaya kepemimpinan yang tercermin pada pemimpin yang fokus terhadap tujuan perusahaan, mendorong komunikasi terbuka dan sikap mengawasi dan memantau penyimpangan dari aturan dan mengambil tindakan korektif. Hal ini mendukung penelitian dari Amunkete dan Rothmann (2015) Khan et al. (2017) yang menyatakan bahwa gaya kepemimpinan otentik berpengaruh signifikan terhadap kepuasan kerja karyawan. Hasil penelitian ini juga mendukung penelitian dari Ayça (2019) yang menyatakan bahwa gaya kepemimpinan otentik berpengaruh positif dan signifikan terhadap kepuasan kerja karyawan hotel.

Tabel 3. Nilai path coeffisients dan nilai t-statistik hasil bootstrapping

\begin{tabular}{lcccl}
\hline Hipotesis & Original Sample & T-statistik & P-value & Keterangan \\
\hline H1 & 0,525 & 4,38 & 0 & Positif (kuat) dan signifikan \\
H2 & 0,765 & 13,697 & 0 & Positif (kuat) dan signifikan \\
H3 & $-0,039$ & 0,301 & 0,764 & Negatif (tidak kuat) dan tidak signifikan \\
\hline
\end{tabular}


H3 - Hubungan gaya kepemimpinan terhadap turnover intentions memiliki nilai t-statistik sebesar 0,301 <1,96 terdapat pengaruh tidak signifikan. Nilai original sample sebesar -0,039 menunjukan arah hubungan negatif. Maka H3 dapat diterima. Nilai p-value sebesar 0,76. Nilai p-value $>5 \%$ terdapat pengaruh tidak signifikan. Dapat diartikan bahwa terdapat pengaruh negatif tidak kuat dan tidak signifikan antara gaya kepemimpinan otentik terhadap turnover intentions karyawan. Faktor turnover intentions tersebut adalah masa kerja pada posisi saat ini, bekerja pada industri hospitality maupun di luar industri hospitality. Dapat disimpulkan bahwa gaya kepemimpinan otentik akan memengaruhi turnover intentions karyawan melalui kepuasan kerja karyawan tersebut. Penelitian ini sejalan dengan hasil penelitian Gatling et al. (2016) yang menyimpulkan bahwa terdapat pengaruh negatif signifikan tidak langsung antara gaya kepemimpinan otentik dengan turnover intentions karyawan yang bekerja di industri hospitality melainkan di mediasi oleh organizational commitment. Hasil penelitian ini mendukung penelitian $\mathrm{Oh}$ dan $\mathrm{Oh}$ (2017) yang menyatakan bahwa gaya kepemimpinan otentik berpengaruh negatif dan tidak langsung terhadap turnover intentions karyawan. Hasil penelitian ini sesuai dengan teori Avolio et al. (2004) yang menyatakan bahwa kepemimpinan otentik berpengaruh terhadap perilaku bawahan. Indentifikasi bawahan terhadap gaya kepemimpinan otentik yang positif memengaruhi emosi positif bawahannya. Hal ini akan mendorong perhatian dan perilaku bawahan yang positif termasuk turnover intentions.

\section{Implikasi Manajerial}

Faktor pengawasan yang dilakukan oleh karyawan tingkat penyelia, asisten manager dan manager dapat ditingkatkan dengan mengadakan pelatihan train for the trainer. Hal ini dapat meningkatkan kemampuan mereka dalam melakukan pengawasan terhadap bawahannya. Dalam mendorong komunikasi terbuka perusahaan dapat menambah sarana komunikasi internal ke atas berupa survey kepada karyawan tentang kepuasan kerja karyawan baik menggunakan formulir khusus dengan media tertulis maupun online, untuk kemudian dievalusi oleh perusahaan per trimester maupun per semester.

Faktor kejenuhan dalam bekerja pada masa kerja saat ini dapat disikapi oleh perusahaan dengan menerapkan keadilan pengaturan jadwal kerja, sehingga mendapatkan keseimbangan antara kehidupan pekerjaan dan kehidupan rutinitas keluarga karyawan.
Job rotation dapat dilakukan oleh perusahaan untuk menghilangkan kejenuhan dalam bekerja dan untuk menambah pengalaman karyawan. Perusahaan akan melakukan penilaian terhadap karyawan dengan kriteria tertentu yang akan diikutsertakan dalam program tersebut. Karyawan yang telah dipilih dan sesuai dengan kriteria penilaian akan diberikan cross training selama periode tertentu mengenai pekerjaan baru yang akan dikerjakan. Pengukuhan dengan surat keputusan atas job rotation diberikan kepada karyawan dan diumumkan secara resmi oleh perusahaan.

\section{KESIMPULAN DAN SARAN}

\section{Kesimpulan}

Dalam penelitian ini dapat disimpulkan kepuasan kerja memiliki pengaruh kuat dan signifikan terhadap turnover intentions karyawan. Semakin tinggi kepuasan kerja karyawan akan menurunkan tingkat turnover intentions karyawan. Faktor kepuasan kerja tersebut adalah pengawasan, situasi pekerjaan, pengakuan dan penghargaan dan promosi. Gaya kepemimpinan otentik memiliki pengaruh kuat dan signifikan terhadap kepuasan kerja karyawan. Gaya kepemimpinan otentik yang tercermin pada pimpinan yang fokus terhadap tujuan perusahaan, mendorong komunikasi terbuka dan sikap mengawasi dan memantau penyimpangan dari aturan dan mengambil tindakan korektif. Semakin mencerminkan perilaku tersebut maka akan semakin meningkatkan kepuasan kerja karyawan. Gaya kepemimpinan otentik berpengaruh tidak kuat dan tidak signifikan terhadap turnover intentions karyawan. Hal ini dapat disimpulkan bahwa kepemimpinan otentik tidak dapat berdiri sendiri dalam memengaruhi tingkat turnover intentions karyawan. Gaya kepemimpinan otentik akan berpengaruh signifikan terhadap turnover intentions karyawan melalui kepuasan kerja karyawan.

\section{Saran}

Saran yang dapat dilakukan sehubungan dengan temuan hasil penelitian ini adalah dalam upaya menekan tingkat turnover intentions karyawan adalah dengan meningkatkan kepuasan kerja karyawan. Dalam upaya tersebut terdapat faktor lain selain gaya kepemimpin. Sehingga penelitian selanjutnya dapat menggunakan variabel lain yang memengaruhi kepuasan kerja dan turnover intentions seperti perceived organizational support. 


\section{DAFTAR PUSTAKA}

Ali JAM, Mohamad IR. 2018. The factor affecting turnover intention with the moderating role of intrinsic intention in Jordanian five-star Hotels. International Journal of Engineering \& Technology 7(4): 6828 - 6832.

Amunkete S, Rothmann S. 2015. Authentic leadership, phsycological capital, job satisfaction and intention to leave in state-owned enterprise. Journal of Pshycology in Africa 25(4): 271-281.

Avolio BJ, Gardner WL, Walumbwa FO, Luthans F, May DR. 2004. Unlocking the mask: A look at the process by which authentic leader impact follower attitudes and behaviors. The Leadership Quarterly 15: $801-823$.

Ayça B. 2019. The impact of authentic leadership behavior on job satisfaction: A research on hospitality enterprises. Procedia Computer Science 158: 790-801.

Azanza G, Moriano JA, Molero F, Jean Pierre LM. 2015. The effects of authentic leadership on turnover intention. Leadership \& Organization Development Journal 36(8): 955-971.

Azeez RO, Jayeoba F, Adeoye AO. 2016. Job satisfaction, turnoverintention and organizational commitment.BVIMSR's Journal of Management Research 8(2): 102-114.

Brown EA. 2011. Hospitality management graduates' perceptions of career factor importance and career factor experience and the relation with turnover intentions. [Disertasi]. Iowa: Iowa State University.

Chen YC, Wang WC, Chu YC. 2010. Structural investigation of the relationship between working satisfaction and employee turnover. The journal of Human Resource and Adult Learning 6(1): 41-50.

Dusek GA, Ruppel CP, Yurova Y, Clarke R. 2014. The role of employee service orientation in turnover in the U.S. Hotel industry. Journal of Organizational Culture, Communication and Conflict 18(2): 87-104.

Fabio BP, Hubeis M, Puspitawati H. 2016. Pengaruh gaya kepemimpinan motivasi kerja terhadap komitmen organisasi yang berimplikasi pada kinerja karyawan. Jurnal Aplikasi Bisnis dan Manajemen 2(1): 91-104.

Gatling A, Kang HJA, Kim JS. 2016. The effect of authentic leadership and organizational commitment on turnover intention. Leadership
\& Organization Development Journal 37(2): 181-199.

Ghozali I. 2011. Structural Equation Modeling. Metode alternatif dengan Partial Least Square (PLS) Semarang: Universitas Diponegoro.

Gunawan I. 2018. Tahun 2018 bisnis di Kota Bogor masih didominasi hotel dan resto. https://bogor. pojoksatu.id/baca/tahun-2018-bisnis-di-kotabogor-masih-didominasi-hotel-dan-resto[11 Des 2018].

Kashyap V, Rangnekar S. 2016. Servant leadership, employer brand perception, trust in leader and turnover intentions: a sequential mediation model. Review Management Science 10: 437461.

Khan S, Muhammad B, Afridi GW, Sarwar I. 2017. Effect of authentic leadership on job satisfaction and employee engagement. City University Research Journal7(1) :151-166.

Kim JH, Kim MK. 2017. The influence of captain's servant leadership on leader trust, job satisfaction, and job performance in a marine industry. International Journal of Economic Prspectives 11(2): 490-499.

Long CS, Perumal P. 2014. Examining the impact of human resources management practices on employees' turnover intention. International Journal of Business and Society. 15(1): 111126.

Mardiana I, Hubeis AVS, Panjaitan NK. 2014. Hubungan kepuasan kerja dengan turnover intentions pada perawat Rumah Sakit Dhuafa. Manajemen IKM 9 (2):119-130.

Nazarudin D, Ma'arif S, Kuswanto S. 2016. Effect of job satisfactionand organizational commitment towards employees turnover intention in pasar tohaga Bogor company. Europan Journal of Business and Management 8(23): 91-100.

Novanda AR, Riadi SS, Lestari D. 2018. Pengaruh servant leadership dan employee voice terhadap job satisfaction pada Bank Bukopin syariah di Samarinda. Jurnal Ilmu Manajemen Mulawarman. 3(4)

Oh J, Oh S. 2017. Authentic leadership and turnover intention: does organizational size matter?. Leadership \& Organizational Development Journal. 38(7): 912 - 926.

Ongori H. 2007. A review of the literature on employee turnover, African Journal of business Management 049 - 054.

Onyebu CM. Omotayo OAR. 2017. Employee Job 
Satisfaction and Organizational Perfomance an Insight From Selected Hotels in Lagos Nigeria, Arabian Journal of Business and Management Review (Kuwait Chapter) 6(10): 48-59.

Robbins SP, Judge TA. 2017. Organizational behavior. Edisi Ke-17.Pearson Education.

Syahronica G, Hakam M S, Ruhana I. 2015. Pengaruh kepuasan kerja dan stress kerja terhadap turnover intention (studi pada karyawan departemen Dunia Fantasi PT Pembangunan Jaya Ancol Tbk), Jurnal Administrasi Bisnis (JAB) 20(1): 1-6.

Weiss DJ, England GW, Lofquit LH. 1967. Minnesota studies in vocational rehabilitation: xxii Manual for the Minnesota satisfaction questionnaire. http://vpr.psych.umn.edu/sites/vpr.dl.umn.edu/ files/monograph_xxii - manual_for_the_mn satisfaction_questionnaire.pdf [1 Okt 2019].

Wells JE, Peachy JW. 2011.Turnover intentions Do leadership behaviors and satisfaction with the leader matter?. Team Performance Management 17(1/2): 23-40.

Widyasari NM, Dewi IGAM, Subudi M. 2017. Pengaruh ketidakamanan kerja dan kompensasi terhadap kepuasan kerja dan turnover intention karyawan besakih beach hotel Denpasar. E-journal Ekonomi dan Bisnis Universitas Udayana 6(5): $2103-2132$.

Wijaya IKP, Putra MS. 2014. Pengaruh kepemimpinan transaksional dan stress kerja terhadap kepuasan kerja karyawan PT Panca Dewata Denpasar Bali. E-journal Manajemen Universitas Udayana 2833-2849.

Yuda IBDP, Ardana IK. 2017. Pengaruh kepuasan kerja dan stress kerja terhadap turnover intention pada karyawan Hotel Holiday Inn Express. E-journal Manajemen UNUD 6(10): 5319-5347.

Zainuddin N, Md Nor Norsyamimi N, Johari H. 2015. Turnover intention(Transactionalledership styles perspective) among electrical and electronics subsector employees in Malaysia. Conference on Business Management Research II (CBMR II 2015):367 - 377 .

Zopiatis A, Constanti P, Theocharous AL. 2014. Job involvement, commitment, satisfaction and turnover: Evidence from hotel employees in Cyprus. Tourism Management 41:129-140 